\title{
PERAN PENGGUNAAN TEKNOLOGI KAMERA DI DALAM HIGIENE PENERBANGAN
}

\author{
Amilya Agustina ${ }^{*}$, Andyka Banyu Sutrisno $^{* *}$, Ferdi Afian ${ }^{* * *}$, Dasti Anditiarina ${ }^{* * * *}$ \\ *Program Studi Kedokteran Penerbangan, Departemen Ilmu Kedokteran Komunitas, \\ Fakultas Kedokteran Universitas Indonesia \\ **Fakultas Kedokteran Universitas Islam Al-Azhar \\ Email : amilya.agustina@gmail.com
}

\begin{abstract}
ABSTRAK
Perkembangan teknologi kamera yang telah maju pesat dapat dimanfaatkan untuk berbagai aspek kehidupan. Salah satunya di aspek hygiene penerbangan, kamera dapat digunakan untuk pengukuran suhu dan deteksi droplet yang besar manfaatnya terutama di masa pandemi Covid-19 seperti saat ini. Berbagai jenis kamera yang dapat digunakan untuk aspek higiene penerbangan antara lain kamera radiasi inframerah, kamera berkecepatan tinggi, dan pelacak partikel. Saat ini bandara telah memanfaatkan teknologi kamera radiasi inframerah. Seiring dengan semakin berkembangnya dunia penerbangan, diharapkan dua jenis kamera lainnya juga dapat dimanfaatkan dalam upaya pencegahan penyebaran penyakit.
\end{abstract}

Kata Kunci: Penerbangan, Covid-19, Kamera, Surveilans

\section{PENDAHULUAN}

Saat ini perkembangan teknologi kamera maju dengan sangat signifikan. Pengaplikasian kamera selain untuk rekreasi, saat ini juga berkembang untuk penelitian, pengukuran suhu, dan sebagai alat deteksi cairan seperti droplet. Pada dunia penerbangan khususnya ketika terjadi pandemi Covid-19 seperti saat ini, penggunaan teknologi kamera dapat diaplikasikan untuk tindakan preventif terjadinya penularan penyakit ketika seseorang melakukan perjalanan menggunakan pesawat terbang. Seperti diketahui, pada tahun 2006 lebih dari 2 juta penumpang melakukan perjalanan menggunakan pesawat terbang. Keadaan tersebut mengindikasikan bahwa perjalanan udara memegang peranan penting dan dapat berpotensi dalam meluasnya penyebaran penyakit menular. Kemungkinan jalur infeksi yang terjadi di dalam pesawat dapat terbagi menjadi 3 kategori yaitu terhisap langsung dalam bentuk droplet atau partikel udara maupun keduanya, kontak langsung dengan cairan tubuh atau kotoran yang berada pada permukaan benda-benda di pesawat, serta penularan yang terjadi pada petugas perawatan melalui kotoran atau cairan tubuh lain yang menempel atau masuk melalui sistem ventilasi. Pada tulisan ini, penulis akan menggambarkan peran teknologi kamera yang dapat digunakan pada dunia penerbangan khususnya aspek higiene (Guide to 
hygiene and sanitation in aviation 2009).

Penulis berharap tulisan ini akan memberikan gambaran pemanfaatan kamera dalam higiene penerbangan, terutama di masa Pandemi Covid-19 saat ini.

\section{PEMBAHASAN}

Teknologi Kamera Dan Perannya

\section{Dalam Higiene}

Saat ini, terdapat berbagai macam jenis kamera yang sudah dikembangkan terkait dengan higiene pada dunia penerbangan antara lain:

\section{Kamera Radiasi Infamerah /}

\section{Infrared Radiation Cameras (IR)}

Kamera radiasi inframerah (IR) merupakan teknologi kamera yang paling sering digunakan pada kehidupan sehari-hari. Perkembangan teknologi kamera radiasi inframerah dilatarbelakangi oleh adanya keterbatasan mata manusia dalam melihat objek dengan pencahayaan yang kurang. Awalnya teknologi ini dikembangkan untuk keperluan militer di Amerika Serikat terkait dengan kebutuhan pandangan malam hari. Teknologi dikembangkan dengan dengan memanfaatkan radiasi yang terpancar dari pada objek-objek yang memiliki suhu diatas nol mutlak, dimana setiap objek yang memiliki suhu diatas nol mutlak akan memancarkan gelombang elektromagnetik yang disebut radiasi termal. Radiasi tersebut dihasilkan oleh gerakan kinetik partikel bermuatan dalam materi. Jumlah radiasi yang dipancarkan akan semakin meningkat dengan adanya faktor suhu. Radiasi tersebut kemudian terdeteksi dan diproses menjadi gambar yang disajikan dalam suatu layar sehingga manusia dapat melihatnya. Dengan teknologi tersebut penggunaan kamera inframerah memungkinkan penggunanya dalam melihat objek tanpa terpengaruh dengan ada atau tidaknya pencahayaan (Bizjan et al. 2017; Mritunjay et al. 2017; Gade \& Moeslund 2014).

Di dalam dunia penerbangan teknologi ini digunakan guna meningkatkan efisiensi dan menekan biaya operasional. Penggunaan yang paling sering dilakukan adalah pada sistem keamanan pesawat serta pada proses perawatan pesawat karena sifatnya yang tidak merusak material. Selain itu penggunaan kamera radiasi inframerah juga dapat digunakan pada sistem pengawasan di darat (bandara). Penggunaan kamera radiasi inframerah yang paling sering dilakukan di bandara adalah untuk mengecek suhu calon penumpang yang akan melakukan perjalanan.

Penggunaan kamera radiasi 
inframerah ini memiliki keuntungan karena dapat melakukan pengecekan tanpa harus terjadi kontak langsung dengan calon penumpang dan pengaplikasiannya dapat langsung digunakan pada lapang pandang yang luas. Kamera radiasi inframerah sendiri dapat dibuat sebagai perangkat pemindai yang dapat menangkap suatu titik atau baris gambar pada satu waktu atau menggunakan penglihatan array dimana semua elemen gambar ditangkap pada waktu yang sama dengan menggunakan setiap elemen detektor di dalam array. Saat ini pengunaan teknologi array lebih sering digunakan karena hasil gambarannya lebih jelas, lebih cepat dan memiliki resolusi spasial yang lebih baik (Gade \& Moeslund 2014; Stumper \& Kraus 2015).

Disaat pandemi suatu penyakit infeksi menular, penggunaan alat yang dapat mengukur suhu secara massal sangat dibutuhkan. Walaupun tidak semua pasien dengan infeksi memunculkan gejala demam, namun demam merupakan salah satu gejala yang paling sering muncul pada individu yang mengidap suatu infeksi. Salah satu jenis kamera radiasi inframerah yang dapat digunakan adalah Infrared Thermal Detection System (ITDS). ITDS sendiri memiliki jenis yang bermacam- macam, tergantung pada produsen yang memproduksinya. Berdasarkan sebuah penelitian yang dilakukan di Amerika Serikat yang membandingkan 3 buah jenis ITDS dengan pengukuran suhu oral dan pelaporan mandiri pasien, ditemukan bahwa dua jenis ITDS (FLIR dan OptoTherm) menunjukan angka sensitivitas dan spesifisitas yang tinggi untuk membedakan individu yang demam dan tidak. Penggunaan kedua sistem tersebut juga relative memakan waktu yang cepat, dimana individu cukup berdiri di depan kamera selama 2-3 detik sebelum akhirnya kedua sistem tersebut dapat menangkap temperatur dari tubuh individu tersebut. Pada percobaan yang lain dimana percobaan dilakukan kepada hewan didapatkan kamera radiasi inframerah dapat mengidentifikasi adanya peradangan di dalam tubuh hewan tersebut. Hal tersebut mungkin dapat terjadi mengingat di dalam proses inflamasi atau peradangan terbentuk suhu yang lebih tinggi dari sekitarnya (Gade \& Moeslund 2014; Nguyen et al 2010). 




Gambar 1. Tampak proses inflamasi pada tungkaikuda yang tertangkap oleh kamera radiasi inframerah (Gade \& Moeslund 2014)

\section{Kamera Berkecepatan Tinggi / Highspeed Cameras}

Dalam beberapa tahun terakhir, pengambilan gambar menggunakan kamera berkecepatan tinggi sudah sangat berkembang. Perkembangan penggunaan teknologi ini awalnya diaplikasikan pada pengujian yang berkaitan dengan kecelakaan mobil, pengembangan balon udara, ilmu olah raga, balistik dan bahan peledak, serta uji coba nuklir. Namun semakin berkembangnya teknologi kamera berkecepatan tinggi akhirnya memungkinkan pengaplikasian teknologi tersebut dalam penelitianpenelitian terkait pembakaran, turbin, aliran supersonik, jet, spray, gelombang kejut serta pada penelitian-penelitian mikrofluida untuk biomedis dan biomekanik. Kemampuan kamera berkecepatan tinggi saat ini sudah tersedia untuk menangkap dengan kecepatan 200 gambar/detik hingga 200 juta gambar/detik. Bentuk kamera juga sudah tersedia dalam bentuk genggam yang portable hingga bentuk yang dapat ditaruh dan mengisi seluruh ruangan. Sistem kamera ini dilengkapi dengan suatu sensor yang disebut Charge-Coupled Device $(C C D)$ atau Complementary MetalOxide Semiconductors (CMOS). Kedua sensor tersebut memiliki fungsi yang sama yaitu mengubah cahaya yang ditangkap oleh lensa yang kemudian diteruskan menjadi elektron yang akan diproses menjadi suatu gambar yang ditampilkan pada layar (Versluis 2013).
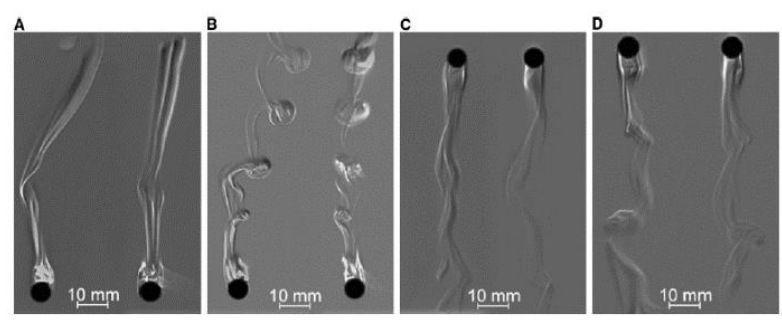

Gambar 2. Hasil tangkapan kamera berkecepatan tinggi (Versluis 2013)

Baru-baru ini para peneliti di Jepang merilis sebuah rekaman video menggunakan kamera berkecepatan tinggi dan memiliki sensitivitas tinggi yang kemudian dilengkapi dengan sinar laser sehingga memungkinkan peneliti dapat menangkap gambaran 
mikrodroplet yang memiliki ukuran 1/10.000 milimeter dan dapat menjadi salah satu cara penyebaran Covid-19. Video tersebut merupakan kolaborasi antara NHK Jepang dan Japanese Association Infectious Diseases. Meskipun hingga saat ini belum diketahui secara pasti seberapa efektif tingkat penularan Covid-19 melalui transmisi droplet, namun berdasarkan jurnal yang dikeluarkan oleh New England Journal of Medicine pada bulan Maret dikatakan bahwa Covid19 ditransmisikan melalui aerosol (Cade 2020).

Pada penelitian yang dilakukan di Jepang ini, fokus penelitian adalah untuk menunjukan seberapa banyak droplet yang tidak dapat terlihat oleh mata manusia keluar dari seseorang saat orang tersebut berbicara, batuk maupun bersin. Selain itu pada penelitian ini ditunjukan berapa lama droplet tersebut dapat bertahan diudara. Hasil penelitian tersebut diperkuat oleh hasil penelitian lain yang dilakukan di Amerika Serikat, dimana tampak penyebaran droplet lebih tinggi ketika seorang individu batuk dibandingkan saat individu tersebut berbicara atau bernafas seperti biasa. Dihubungkan dengan sektor penerbangan, kabin pesawat memiliki tingkat kepadatan penumpang yang tinggi dengan waktu

Jurnal Kedokteran

Vol. 06 No. 01 Desember 2020 pemaparan yang lama. Penerbangan komersial dapat berlangsung dari 1 jam hingga 20 jam dihitung dari gate ke gate, selama periode tersebut penumpang dapat berisiko terpapar kontaminan yang mungkin terdapat pada kabin pesawat. Situasi itu semakin membahayakan selama periode pandemi seperti influenza, tuberculosis, SARS ataupun Covid-19 yang saat ini sedang terjadi. Sehingga dibutuhkan suatu teknologi atau alat yang dapat mendeteksi sebaran droplet yang dapat terpasang didalam kabin pesawat atau pun di bandara, sehingga dapat membantu dalam pencegahan penularan infeksi maupun dalam proses pembersihan pesawat (Cade 2020; Gupta et al 2011).

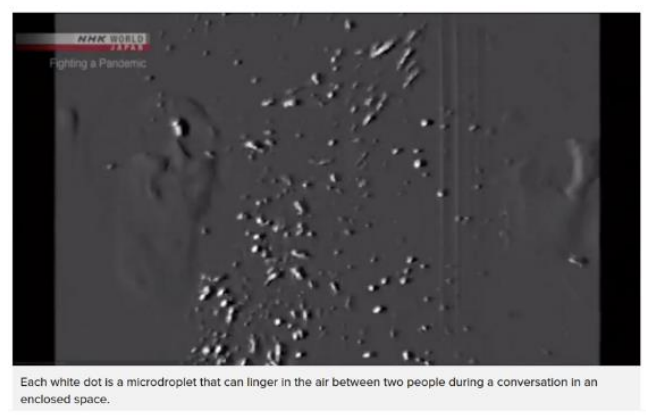

Gambar 3. Gambaran mikrodroplet yang tertangkap oleh kamera (Cade 2020)

\section{Teknologi Pelacak Partikel}

Pelacakan partikel secara komprehensif dapat menjelaskan aktivitas dan perilaku kompleks di dalam sebuah objek lunak ataupun 
suatu aliran air. Dengan teknik pelacakan partikel, seseorang dapat secara langsung melacak objek biologis seperti molekul biologi tunggal, virus, bakteri dan sel-sel motil lain. Terdapat beberapa jenis teknologi pelacakan partikel. Pada tulisan ini, teknologi pelacakan partikel yang akan dibahas adalah Hyper spectral Cameras dan Particles Tracing Velocimeter (PTV) (Patel et al 2018).

Mikroorganisme, termasuk bakteri, virus dan jamur di dalam industri makanan terkait erat dengan kualitas dan keamanan dari makanan tersebut. Hampir seperempat dari pasokan makanan global rusak dikarenakan aktivitas mikroba saja, dan kontaminasi menjadi sumber paling umum dari pada penyakit infeksi melalui makanan (foodborne diseases). Mikroorganisme tersebut dapat mempercepat proses pembusukan makanan saat penyimpanan yang berakibat kerugian ekonomi, selain itu mikroorganisme tersebut juga dapat menyebabkan morbiditas dan mortalitas pada orang yang tidak sengaja mengkonsumsi produk makanan yang terkontaminasi tersebut. Oleh karena itu untuk mengatasinya dilakukan pencarian teknik yang dapat menganalisis secara cepat dan efektif terhadap kontaminasi mikrobiologi pada makanan. Salah satu teknik yang dikembangkan yaitu Spectral

Jurnal Kedokteran

Vol. 06 No. 01 Desember 2020
Imaging Techniques. Prinsip yang mendasari teknik ini dalam mendeteksi mikroorganisme didasarkan pada asumsi metabolit yang dapat memberikan sidik jari yang khas untuk menunjukan kontaminasi mikroorganisme pada makanan.

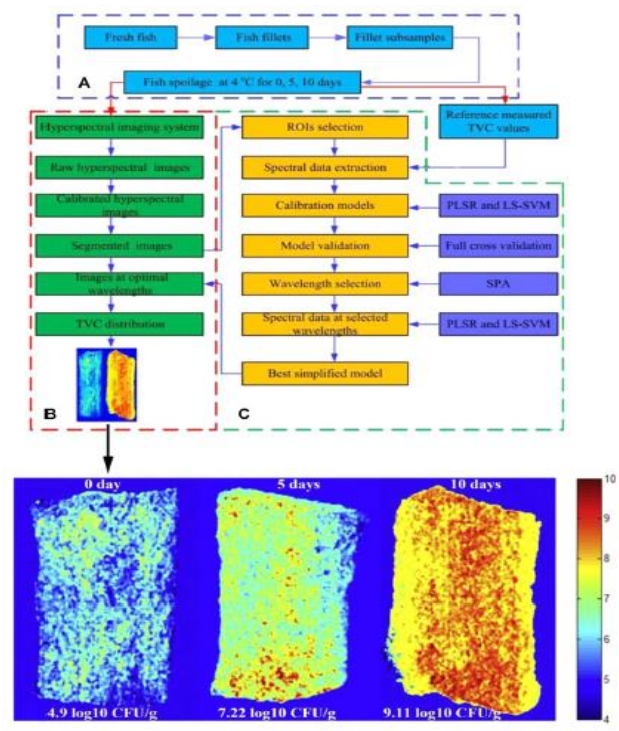

Gambar 4. Langkah-langkah penggunaan Spectral Imaging Techniques dalam mendeteksi kontaminasi mikroorganisme pada makanan (Wang et al 2018)

Setiap posisi pada spesimen dapat menampilkan sidik jari spektral yang unik yang dapat digunakan untuk mengkarakterisasi komponen kimianya. Dengan demikian penggunaan teknik tersebut dapat digunakan selain untuk mengidentifikasi dan menghitung komposisi kimia, juga dapat memberikan gambaran visualisasi 
distribusinya secara bersamaan. Pada teknik ini, Total Viable Count (TVC) dari bakteri menjadi indikator untuk menilai tingkat kontaminasi produk makanan, dimana apabila TVC bakteri berada melebihi batas tertentu maka makanan tersebut dianggap berbahaya dan dapat menyebabkan masalah kesehatan bagi konsumennya (Wang et al 2018).

Selain perannya pada pendeteksian mikroorganisme pada makanan, penggunaan teknologi kamera juga dapat digunakan pada air. Kontaminasi mikroorganisme pada air minum juga menjadi masalah utama di seluruh dunia karena masih merupakan sumber penyakit utama penyakit yang ditularkan melalui air (water-borne diseases) baik di negara-negara berkembang atau pun di negara maju. Pendeteksian bakteri patogen pada air minum merupakan masalah penting bagi penyediaan air karena dapat berdampak kritis terhadap kesehatan masyarakat (Masaaki 2014).

Pada dunia penerbangan, air menjadi bagian penting yang harus tersedia baik di bandara maupun di atas pesawat. Proses penyediaan air di bandara maupun pesawat melalui proses panjang yang diawali dari sumber air hingga tersimpan di bandara atau pun pesawat, proses tersebut berpotensi mengalami kontaminasi mikroorganisme apabila prosesnya tidak dilakukan dengan baik (Guide to hygiene and sanitation in aviation 2009). ${ }^{1}$

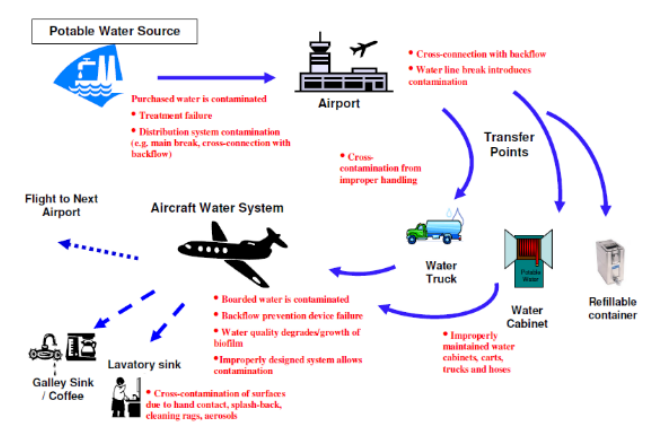

Gambar 5. Proses penyediaan dan transportasi air bersih di bandara dan pesawat terbang beserta potensi bahaya yang dapat terjadi (Guide to hygiene and sanitation in aviation 2009).

Meskipun saat ini sudah terdapat metode mikrobiologi tradisional seperti perhitungan pada lempengan dan kultur sel yang menjadi standar emas untuk mengkonfirmasi keberadaan patogen pada air, namun prosesnya sering membutuhkan waktu sekitar 24-48 jam untuk mendapatkan hasilnya. Untuk pemeriksaan kultur sel virus bahkan mungkin membutuhkan waktu 7-10 hari. Selain prosesnya yang lama, seperti yang ditampilkan pada gambar 5., proses kontaminasi juga dapat terjadi ketika proses pemindahan sehingga tidak memungkinkan lagi 
untuk dilakukan pemeriksaan sesuai dengan standar emasnya tersebut. Sehingga dibutuhkan suatu teknologi yang dapat mendeteksi bahaya patogen pada air yang dapat digunakan secara cepat,guna melindungi konsumen dari bahaya patogen tersebut (Masaaki 2014).

Saat ini sistem teknologi kamera yang terintergrasi dengan sensor pelacak menjadi teknologi yang sedang digemari dalam melakukan investigasi terhadap aliran dikarenakan fleksibilitas dan skalabilitasnya. Sistem tersebut disebut Particles Image Velocimeter (PIV) dan Particles Tracing Velocimeter (PTV). Keduanya merupakan teknologi berbasis gambar yang saat ini dapat digunakan dalam pencampuran bahan kimia, melihat proses distribusi obat, menghitung dan memilah sel, serta pendeteksian dan pelacakan objek yang berada pada suatu aliran air. Kedua sistem kamera tersebut terintregasi dengan sebuah sumber cahaya, mikroskop dan layar sehingga dapat menangkap gambar partikel-pertikel kecil pada suatu aliran air (Ergin et al 2018).

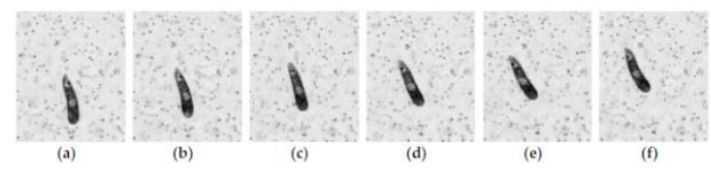

Gambar 6. Gambaran pergerakan

Euglena Gracilis yang tertangkap oleh sistem PIV (Ergin et al 2018)

Perbedaan yang ada diantara penggunaan PTV dan PIV adalah, resolusi yang dihasilkan oleh sistem PTV lebih baik dibandingkan sistem PIV. Selain itu ketika PIV membutuhkan perangkat lunak tambahan untuk dapat memproses gambar, PTV sudah memiliki kamera dengan fitur pemrosesan gambar yang sudah terintregasi dengan kamera berkecepatan tinggi pada sistem tersebut (Dabiri \& Pecora 2019; Gennari et al 2015).

Kedua system pelacak partikel tersebut seperti yang sudah dijelaskan sebelumnya, merupakan suatu sistem yang terintergrasi dan salah satu komponen pentingnya adalah kamera. Baik sistem PTV maupun PIV menggunakan kamera berkecepatan tinggi yang memiliki sensor khusus baik CCD ataupun CMOS. Pengidentifikasian partikel dilakukan dengan suatu algoritma yang dapat menentukan gambaran dan lokasi dari partikel yang tertangkap oleh kamera tersebut. Kedua sistem tersebut juga dapat mengidentifikasi partikel secara 
2 dimensi dan 3 dimensi. Pengaturan setiap sistem tersebut memiliki kesamaan baik PIV 2D dengan PTV 2D, maupun PIV 2D dengan PTV 3D (Dabiri \& Pecora 2019).

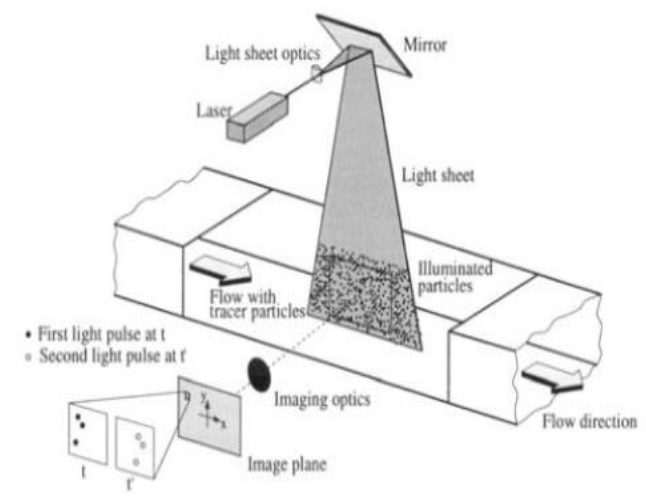

Gambar 7. Skema penggunaan PTV 2D pada terowongan air (Dabiri \& Pecora 2019).

Pada pengaturan 2D, kamera diposisikan tegak lurus dengan posisi cahaya, yang kemudian disinkronisasikan sehingga dapat menangkap partikel secara tepat waktu. Pada pengaturan 3D, perbedaannya adalah penggunaan beberapa kamera disinkronisasikan dengan jumlah volume yang ingin dilakukan pelacakan. Dengan perkembangan teknologi ini, proses pengidentifikasian air dapat dilakukan lebih mudah tanpa melalui proses yang lama. Pada penelitian yang lain, penggunaan PTV dan PIV juga berguna untuk melakukan pelacakan partikel pada aliran udara. Pada penelitian tersebut, pengujian dilakukan menggunakan partikel pelacak dimana keduanya mampu melacak partikel tersebut. Walaupun begitu, menurut hasil uji coba tersebut penggunaan PIV lebih baik dalam memberikan informasi pelacakan dibandingkan penggunaan PTV (Dabiri \& Pecora 2019; Sijie et al 2015).

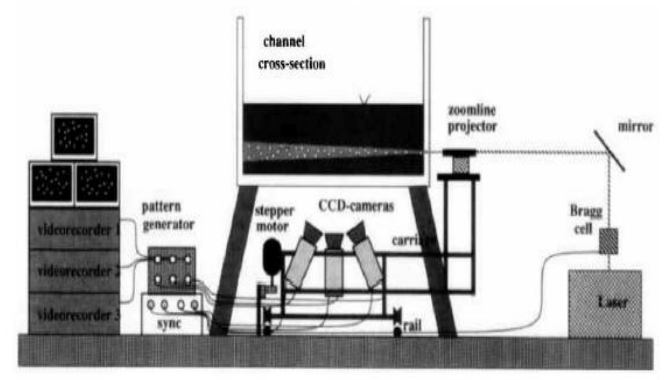

Gambar 8. Skema penggunaan PTV 3D pada terowongan air (Dabiri \& Pecora 2019)

\section{PENUTUP}

Selama beberapa tahun ini tingkat kemajuan teknologi kamera berkembang sangat pesat. Teknologi kamera yang diawal pembuatannya hanya digunakan untuk rekreasi berkembang menjadi teknologi yang dapat digunakan dalam penelitian maupun kehidupan sehari-hari, salah satunya pada sektor penerbangan. Teknologi kamera yang dapat digunakan di sektor penerbangan khususnya aspek higiene antara lain kamera radiasi inframerah, kamera kerkecepatan tinggi dan kamera dengan teknologi pelacak partikel. Namun untuk saat ini penggunaan teknologi kamera di aspek 
higiene penerbangan hanya terbatas pada penggunaan kamera radiasi inframerah dalam melakukan skrining pada penumpang di Bandara. Penggunaan teknologi kamera inframerah ini sangat dirasakan manfaatnya terutama di masa pandemi Covid-19 saat ini namun diharapkan dikemudian hari dengan semakin majunya dunia penerbangan, pemanfaatan teknologi kamera yang lain seperti kamera berkecepatan tinggi, hyperspectral cameras, PIV ataupun PTV dapat diaplikasikan pada proses mitigasi terkait higiene baik di pesawat, bandara, katering makanan maupun proses penyediaan air bersih.

\section{DAFTAR PUSTAKA}

Bizjan B, Kuznetsov A, Jeromen A, et al 2017, 'High-speed camera thermometry of laser droplet generation', Appl Therm Eng, vol. 110, hh. 298-305.

Cade DL 2020, 'Scientists use highsensitivity camera to capture 'microdroplets' that may transmit virus', dilihat 6 Mei 2020, https://petapixel.com/2020/04/03/sci entists-use-high-sensitivity-camerato-capture-microdroplets-that-maytransmit-virus/ .

Dabiri D, Pecora C 2019, 'Particle tracking velocimetry', IOP Publishing, DOI: 10.1088/978-07503-2203-4.

Ergin F, Watz B, Gade-Nielsen N 2018, 'A review of planar PIV systems and image processing tools for lab-onchip microfluidics', Sensors, vol. 18, hh. 3090.

Gade R, Moeslund TB 2014, 'Thermal cameras and applications: a survey', Mach Vis Appl, vol. 25, hh. 245-262.

Jurnal Kedokteran

Vol. 06 No. 01 Desember 2020
Gennari O, Battista L, Silva B, et al 2015, 'Investigation on cone jetting regimes of liquid droplets subjected to pyroelectric fields induced by laser blasts', Appl Phys Lett, vol. 106, hh. 054103.

Gupta JK, Lin C-H, Chen Q 2011, 'Inhalation of expiratory droplets in aircraft cabins: Inhalation of expiratory droplets', Indoor Air, vol. 21, hh. 341-350.

Masaaki K SP 2014, 'Rapid detection technologies for monitoring microorganisms in water', Biosens $J$, vol. 03.

Mritunjay R, Maity T, Yadav RK 2017, 'Thermal imaging system and its time applications: survey', J Eng Technol, vol. 6, hh. 290-303.

Nguyen AV, Cohen NJ, Lipman H, et al 2010, 'Comparison of 3 infrared thermal detection systems and selfreport for mass fever screening' , Emerg Infect Dis, vol. 16, hh. 17101717.

Patel M, Leggett SE, Landauer AK, et al 2018. 'Rapid, topology-based particle tracking for high-resolution measurements of large complex 3D motion fields', Sci Rep, vol 8, hh. 5581.

Sijie Fu, Pascal-Henry Biwolé, Mathis C. A 2015, 'Comparative study of particle image velocimetry (PIV) and particle tracking velocimetry (PTV) for airflow measurement', Epub,

DOI: 10.5281/ZENODO.1337781.

Štumper M, Kraus J 2015, 'Thermal imaging in aviation', MAD - Mag Aviat Dev, vol. 3, hh. 13.

Versluis M 2013, 'High-speed imaging in fluids', Exp Fluids, vol. 54, hh. 1458.

Wang K, Pu H, Sun D-W 2018, 'Emerging spectroscopic and spectral imaging techniques for the rapid detection of microorganisms: an overview', Compr Rev Food Sci Food Saf, vol. 17, hh. 256-273.

World Health Organization 2009, 'Guide to hygiene and sanitation in aviation', 3rd ed, Geneva. 